\title{
Estrogenic mycotoxins in surface waters of the Rico Stream micro- basin, São Paulo, Brazil: occurrence and potential estrogenic contribution
}

Elissandro Soares Emídio ${ }^{+}$, Claudia Pereira da Silva®, Mary Rosa Rodrigues de Marchi®

São Paulo State University (Unesp), Institute of Chemistry, 55 Prof. Francisco Degni St, Araraquara, São Paulo, Brazil

${ }^{+}$Corresponding author: Elissandro Soares Emídio, Phone: +55 16 3301-9735 email address: elissandro_se@yahoo.com.br

\section{ARTICLE INFO}

Article history:

Received: July 21, 2019

Accepted: December 11, 2019

Published: April 1, 2020

\author{
Keywords: \\ 1. estrogenic mycotoxins \\ 2. occurrence \\ 3. surface waters \\ 4. estrogenicity \\ 5. southeast Brazil
}

\begin{abstract}
The aim of this study was to assess the occurrence of zearalenone (ZEN) and its metabolites zearalanone (ZAN), $\alpha$-zearalenol $(\alpha-$ ZEL), $\quad \beta$-zearalenol $\quad(\beta$-ZEL) $\alpha$ zearalanol $(\alpha-Z A L)$, and $\beta$-zearalanol $(\beta-Z A L)$ in the surface waters of northern São Paulo state (Brazil) and to evaluate the associated potential estrogenic contribution to the aquatic environment. The determination of the estrogenic mycotoxins in water samples from the Rico Stream microbasin yielded levels of up to $59 \mathrm{ng} \mathrm{L}^{-1}$ and their corresponding calculated
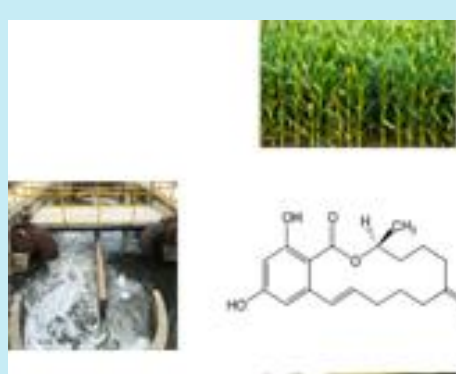

estrogenic equivalent (cEEQ) values were between $<0.03$ and $1.4 \mathrm{ng} \mathrm{L}^{-1}$, which are associated with negative effects on the reproduction and growth of some fish species. The physicochemical and microbiological parameters were evaluated to determine the water quality in the Rico stream region. This study revealed the first data about the presence of estrogenic mycotoxins in the Brazilian river waters and emphasizes the need to include these substances in future public policies concerning water quality, since these compounds are not yet legally regulated. From an environmental aspect, it is necessary to take into account the continuous introduction into surface water of microcontaminants associated with wastewater effluent, such as estrogenic mycotoxins.
\end{abstract}

\section{Introduction}

Among the hundreds of mycotoxin-producing fungi, the genus Fusarium is considered one of the most prevalents in terms of animal health implications and economic damage ${ }^{1}$. Resorcyclic acid lactones (RALs) are compounds that exhibit endocrine disruptive behavior and are produced by fungi of the genus Fusarium ${ }^{2}$. The representative mycotoxin of this class of RALs is zearalenone (ZEN), cited among the most common mycotoxins worldwide ${ }^{3}$.

In Brazil, there have been few studies on the incidence of fusariotoxins. For example, the occurrence of ZEN was reported in maize ${ }^{4}$, rice $^{5}$ and wheat ${ }^{6}$ in the south and southeast Brazilian regions. Fusariotoxins are mostly produced under high humidity and at temperatures of approximately 20 to $26^{\circ} \mathrm{C}$. The Brazilian climate offers good conditions for these toxins to be present in grains used in the diets of animals and humans ${ }^{7}$.

The incidence of ZEN and its metabolites has been reviewed extensively in food for humans and animals ${ }^{8}$. However, little is known about its impact or environmental distribution, with few studies having been carried out concerning these attributes ${ }^{9}$. Some publications have reported the occurrence of ZEN in surface water, groundwater 
and effluent from sewage treatment plants and industries, with concentrations of ZEN or its metabolites ranging from undetected levels to $4120 \mathrm{ng} \mathrm{L}^{-1}{ }^{10}$. Zearalanone (ZAN) and $\beta$ zearalenol ( $\beta$-ZEL) have rarely been detected or analyzed in aqueous environmental samples. ZEN and its metabolites can contribute to the overall estrogenic activity in the environment and therefore could pose a risk to wild fish in their natural habitat, as indicated by a zebrafish study in which there was a change in the reproductive capacity of animals exposed to low concentrations of estrogenic compounds (100 to $3200 \mathrm{ng} \mathrm{L}^{-1}$ ) for 21 days $^{3}$.

Some studies conducted in Brazil have reported the occurrence of endocrine disruptors in surface waters, with monitoring results showing the periodic presence of these substances in natural waters, suggesting that different sources in addition to untreated sewage contribute to the input into water sources ${ }^{11}$. Possible aqueous environmental contamination routes of estrogenic mycotoxins include: drainage water from fields cultivated with infected plants, runoff from livestock facilities or manure applications to field crops and human excretions in urban wastewaters ${ }^{12}$.

The purpose of this study was to examine for the first time the occurrence of estrogenic mycotoxins in Brazilian water samples, using dispersive liquidliquid microextraction (DLLME) followed by liquid chromatography-tandem mass spectrometry and to identify possible sources of contamination, seasonal variations and potential contribution to total estrogenic activity in the southeast region of Brazil (São Paulo state).

\section{Experimental}

\subsection{Standards and reagents}

ZEN, $\alpha$-ZEL, $\beta-Z E L, \alpha-Z A L, \beta-Z A L$ and ZAN standards were all obtained from Sigma Aldrich (St. Louis, MO, USA) with purities of at least $98 \%$. The zearalenone-d6 (surrogate internal standard, ZEN-d6) was supplied from Toronto Research Chemicals (North York, ON, Canada). Acetonitrile $(\mathrm{ACN})$ and methanol $(\mathrm{MeOH})$, both HPLC grade were provided from J. T. Baker (Phillipsburg, NJ, USA). Bromocyclohexane was acquired from Alfa Aesar (MA, USA). Hydrochloric acid $(37 \% \mathrm{~m} / \mathrm{v})$ and sodium hydroxide were purchased from J.T. Baker (Phillipsburg, NJ, USA) to adjust the $\mathrm{pH}$ of water samples. Deionized water was obtained using a Milli-Q purification system (Bedford, MA, USA).

\subsection{Sampling area}

The Rico Stream microbasin is localized in the northeast region of São Paulo state and consists of the municipalities Jaboticabal, Taquaritinga, Monte Alto, Guariba and Santa Ernestina (Fig. 1), occupying an area of approximately $563 \mathrm{~km}^{2}$ at an altitude between 498 and $754 \mathrm{~m}$.

The Rico Stream is the main source of water in the micro-basin, with a total of $59.2 \mathrm{~km}$ of watercourse length discharging into the Mogi Guaçu River. Because of its high representativeness in the region, Rico Stream stands out as the main supply of water for the city of Jaboticabal (population ca. 75,000). Anthropogenic impacts on the environment may occur both directly or indirectly, due to effluent discharges from domestic sewage treatment plants of the Monte Alto municipality and animal husbandry (poultry, swine and cattle) ${ }^{13}$.

In accordance with the classification proposed by Köeppen, the region possesses a climate defined as Aw, characterized as tropical with summer rainfall and dry winters. The average temperature is $23{ }^{\circ} \mathrm{C}$, and the total average annual rainfall is $1405 \mathrm{~mm}$ occurring mainly during the period from October to March, with the dry season extending from April to September ${ }^{14}$. 


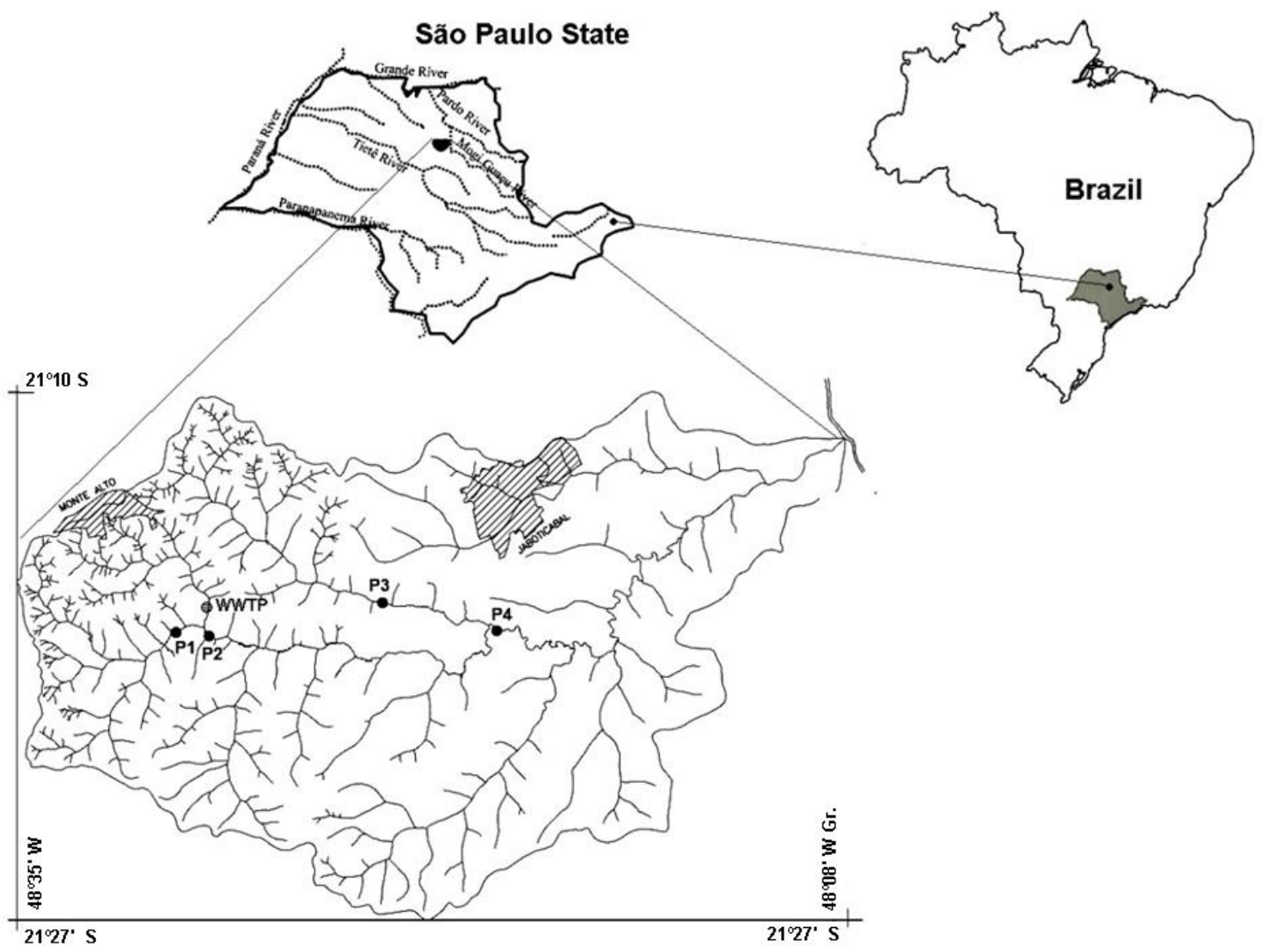

Figure 1. Map of the studied area showing the location of four sampling sites (Adapted from Pissarra et al. ${ }^{15}$ and Takahashi et al. ${ }^{16}$ ).

\subsection{Sample collection and pretreatment}

The collection of water samples was performed from October 2014 to July 2015 (ten sampling campaigns) at four different sampling sites located in the Rico Stream, except one that was located in Tijuco Stream (stream tributary) between the municipalities of Monte Alto and Jaboticabal. References sites: P1 situated near the Rico Stream source with minor contamination impacts and upstream of wastewater treatment plant (WWTP) effluent discharge $\left(21^{\circ} 18^{\prime} 37.26 " S\right.$; $\left.48^{\circ} 27^{\prime} 39.49^{\prime \prime} \mathrm{W}\right)$; P2 situated at the downstream discharge point of the WWTP, which also represents the influence of input from agricultural industry and runoff from livestock facilities or fields receiving livestock manure applications $\left(21^{\circ} 18^{\prime} 46.08^{\prime \prime} \mathrm{S} ; 48^{\circ} 26^{\prime} 56.33 \mathrm{\prime W}\right)$; P3 located in the Tijuco Stream, upstream of the public water supply and near the confluence with the Rico Stream $\left(21^{\circ} 17^{\prime} 56.08^{\prime \prime S}\right.$; 48 $\left.22^{\prime} 31.69^{\prime \prime} \mathrm{W}\right)$ and P4 located freshwater abstraction site for the public water supply to Jaboticabal city $\left(21^{\circ} 18^{\prime} 36.07^{\prime \prime} \mathrm{S}\right.$; $48^{\circ} 19^{\prime} 26.11^{\prime \prime}$ ).

The water samples were collected at $30 \mathrm{~cm}$ depth in $1000 \mathrm{~mL}$ amber glass bottles, previously rinsed thoroughly with ultrapure water. After collection, samples were transported to the laboratory under refrigeration at $4{ }^{\circ} \mathrm{C}$ (ice packs) and processed within $48 \mathrm{~h}$. In the laboratory prior to extraction, the samples were filtered through a glass fiber filter with a pore size of $0.6 \mu \mathrm{m}$ (Macherey-Nagel GF-3), acidified to $\mathrm{pH} 4$ and spiked to $200 \mathrm{ng} \mathrm{L}^{-1}$ with an internal surrogate $\left(\mathrm{ZEN}-\mathrm{d}_{6}\right)$. Samples were then immediately extracted and analyzed using the previously developed and validated dispersive liquid-liquid microextraction (DLLME) method and liquid chromatography coupled to tandem mass spectrometry (LC-MS/MS $)^{17}$. 
2.4 Determination of physicochemical and microbiological parameters

A total of twelve physicochemical and microbiological parameters were used to assess water quality control and pollution. Parameters such as fecal coliforms, total organic carbon, chemical oxygen demand (COD), biochemical oxygen demand (BOD), total phosphorous, total nitrogen, nitrate, nitrite, ammoniacal nitrogen, potassium, turbidity and total dissolved solids were determined using standard procedures described by the American Public Health Association ${ }^{18}$.

\subsection{Analytical Methodology}

An aliquot of $10 \mathrm{~mL}$ of the water sample was added into a $12 \mathrm{~mL}$ conical glass centrifuge tube with screw cap. Thereafter, $100 \mu \mathrm{L}$ of bromocyclohexane (extraction solvent) was added to the sample solution. The mixture was then vigorously shaken using a vortex mixer at $2500 \mathrm{rpm}$ for $120 \mathrm{~s}$. After centrifugation for $10 \mathrm{~min}$ at $3500 \mathrm{rpm}$, the organic sedimented phase was collected in a glass insert $(300 \mu \mathrm{L})$ using a $100 \mu \mathrm{L}$ Hamilton microsyringe and was evaporated in a $\mathrm{N}_{2}$ flow. The residue was reconstituted in $80 \mu \mathrm{L}$ of $\mathrm{MeOH} / 0.1 \%$ formic acid in $\mathrm{H}_{2} \mathrm{O}(50: 50$, v/v) and injected into the LC-ESI-MS/MS for analysis.

\subsection{Instrumentation}

The HPLC analyses were carried out on an Agilent 1200 series LC system coupled with a 3200 QTRAP mass spectrometer (Applied Biosystems/MDS Sciex Instruments) with an electrospray ionization source (ESI). The mass spectrometric parameters selected for experiments of full scan and ion fragmentation were as follow: ion spray voltage of $-4 \mathrm{kV}$, curtain gas (nitrogen) at $15 \mathrm{psi}$, auxiliary gas at $40 \mathrm{psi}$, nebulizer gas at $50 \mathrm{psi}$, source temperature at $600{ }^{\circ} \mathrm{C}$, interface heater and entrance potential of $-10 \mathrm{~V}$. Chromatographic separation of the estrogenic mycotoxins was achieved at $40{ }^{\circ} \mathrm{C}$ using a Gemini $\mathrm{C}_{18}$ column $(150 \times 4.6 \mathrm{~mm}, 5 \mu \mathrm{m}$; Phenomenex, Torrance, CA, USA) preceded by a Phenomenex $\mathrm{C}_{18}$ column guard $(4 \times 3 \mathrm{~mm})$. The mobile phase consisted of $0.1 \%$ formic acid in water $(48 \%, \mathrm{v} / \mathrm{v})$, acetonitrile $(25 \%, \mathrm{v} / \mathrm{v})$ and methanol $(27 \%, \mathrm{v} / \mathrm{v})$, with a flow rate of $1.0 \mathrm{~mL} \mathrm{~min}{ }^{-1}$ for $17 \mathrm{~min}$ and injection volume was set to $20 \mu \mathrm{L}$. Applied Biosystems Analyst 1.5 software was used for data acquisition.

\subsection{Quality assurance/quality control}

The calibration was performed by internal standardization method with matrix-matched blank samples. The calibration curve consists of eight different concentration values, in the range 8 to $680 \mathrm{ng} \mathrm{L}^{-1}$. The analytes were extracted by DLLME prior to chromatographic analysis for each point of the calibration curve. The calibration curve was obtained from the ratio between the peak areas of analytes and the internal standard versus the analyte concentrations (ng $\left.\mathrm{L}^{-1}\right)$. Every experimental point was analyzed in triplicate. The extraction efficiency (recovery percentage) of the analytes was evaluated by spiked with $200 \mathrm{ng} \mathrm{L}^{-1}$ of the internal surrogate (ZEN-d6) to all river water samples.

\subsection{Estrogenicity}

The estrogenic potential of the aqueous samples was calculated in equivalent activity compared to the reference substance (natural hormone 17- $\beta$ estradiol $)^{19}$. The potential contribution of each estrogenic mycotoxin to the total estrogenic activity of the surface waters was calculated according to the Eq. 1:

$$
c E E Q=\text { concentration of estrogenic mycotoxin } \times R P
$$

where cEEQ is the calculated estrogenic equivalent (17- $\beta$-estradiol) of a specific estrogenic mycotoxin and RP is the relative potency of the mycotoxin in an individual bioassay.

\section{Results and Discussion}

\subsection{Occurrence of estrogenic mycotoxins in environmental samples}

The results obtained from the collected samples (during the period of October 2014 to July 2015) are shown in Tab. 1. Surrogate recovery values (ZEN-d6) ranged from 71 to $124 \%$ from the extraction method. These recovery values are 
suitable when dealing with complex environmental samples such as the river water analyzed in this study.

Table 1. Estrogenic mycotoxin concentrations $\left(\mathrm{ng} \mathrm{L}^{-1}\right)$ at four sampling sites in the Rico Stream micro-basin.

\begin{tabular}{|c|c|c|c|c|c|c|c|c|}
\hline \multirow[t]{2}{*}{ Compounds } & \multicolumn{3}{|c|}{ October/2014 } & \multirow[b]{2}{*}{ P4 } & \multicolumn{3}{|c|}{ November/2014 } & \multirow[b]{2}{*}{ P4 } \\
\hline & P1 & P2 & P3 & & P1 & $\mathbf{P 2}$ & P3 & \\
\hline$\beta-Z A L$ & n.d. ${ }^{\mathrm{c}}$ & n.d. & n.d. & n.d. & 48 & n.d. & n.d. & n.d. \\
\hline$\beta$-ZEL & n.d. & $<40^{\mathrm{b}}$ & n.d. & n.d. & n.d. & n.d. & n.d. & n.d. \\
\hline$\alpha-Z A L$ & n.d. & n.d. & n.d. & n.d. & $<20^{\mathrm{b}}$ & $<20^{\mathrm{b}}$ & 27 & $<20^{\mathrm{h}}$ \\
\hline$\alpha-Z E L$ & n.d. & n.d. & n.d. & n.d. & n.d. & n.d. & n.d. & n.d. \\
\hline ZAN & n.d. & n.d. & n.d. & n.d. & $<8^{\mathrm{b}}$ & n.d. & n.d. & n.d. \\
\hline ZEN-d ${ }_{6}{ }^{\mathrm{a}}$ & 112 & 108 & 107 & 106 & 107 & 96 & 76 & 91 \\
\hline ZEN & $<8^{b}$ & $<8^{\mathrm{b}}$ & $<8^{\mathrm{b}}$ & $<8^{\mathrm{b}}$ & $<8^{b}$ & $<8^{\mathrm{b}}$ & $<8^{\mathrm{b}}$ & $<8^{\mathrm{b}}$ \\
\hline \multirow[t]{2}{*}{ Compounds } & \multicolumn{3}{|c|}{ December/2014 } & & \multicolumn{3}{|c|}{ January/2015 } & \\
\hline & P1 & P2 & P3 & P4 & P1 & P2 & P3 & P4 \\
\hline$\beta-Z A L$ & n.d. & n.d. & n.d. & n.d. & n.d. & n.d. & n.d. & n.d. \\
\hline$\beta$-ZEL & n.d. & n.d. & n.d. & n.d. & n.d. & n.d. & n.d. & n.d. \\
\hline$\alpha-\mathrm{ZAL}$ & n.d. & n.d. & n.d. & n.d. & n.d. & n.d. & n.d. & n.d. \\
\hline$\alpha-Z E L$ & n.d. & n.d. & n.d. & n.d. & n.d. & n.d. & n.d. & n.d. \\
\hline ZAN & n.d. & n.d. & n.d. & n.d. & n.d. & n.d. & n.d. & n.d. \\
\hline ZEN- $\mathrm{d}_{6}^{\mathrm{a}}$ & 89 & 80 & 91 & 93 & 112 & 81 & 74 & 77 \\
\hline ZEN & n.d. & n.d. & n.d. & n.d. & 22 & 29 & 25 & 27 \\
\hline \multirow[t]{2}{*}{ Compounds } & \multicolumn{3}{|c|}{ February/2015 } & & \multicolumn{3}{|c|}{ March/2015 } & \\
\hline & P1 & P2 & P3 & P4 & P1 & P2 & P3 & P4 \\
\hline$\beta-Z A L$ & n.d. & n.d. & n.d. & n.d. & n.d. & n.d. & n.d. & n.d. \\
\hline$\beta$-ZEL & n.d. & n.d. & n.d. & n.d. & n.d. & n.d. & n.d. & n.d. \\
\hline$\alpha-Z A L$ & n.d. & n.d. & n.d. & n.d. & $<20^{\mathrm{b}}$ & n.d. & n.d. & n.d. \\
\hline$\alpha-Z E L$ & n.d. & n.d. & n.d. & n.d. & n.d. & n.d. & n.d. & n.d. \\
\hline ZAN & n.d. & n.d. & n.d. & n.d. & n.d. & n.d. & n.d. & n.d. \\
\hline ZEN-d ${ }^{a}$ & 118 & 105 & 97 & 97 & 73 & 71 & 115 & 100 \\
\hline ZEN & n.d. & n.d. & n.d. & n.d. & 59 & 46 & 51 & 42 \\
\hline \multirow{2}{*}{ Compounds } & \multicolumn{3}{|c|}{ April/2015 } & & \multicolumn{3}{|c|}{ May/2015 } & \\
\hline & P1 & $\mathbf{P 2}$ & P3 & P4 & P1 & P2 & P3 & P4 \\
\hline$\beta-Z A L$ & n.d. & n.d. & n.d. & n.d. & n.d. & n.d. & n.d. & n.d. \\
\hline$\beta$-ZEL & n.d. & n.d. & n.d. & n.d. & n.d. & n.d. & n.d. & n.d. \\
\hline$\alpha-Z A L$ & n.d. & n.d. & n.d. & n.d. & n.d. & n.d. & n.d. & n.d. \\
\hline$\alpha-Z E L$ & n.d. & n.d. & n.d. & n.d. & $<20^{b}$ & n.d. & n.d. & n.d. \\
\hline ZAN & n.d. & n.d. & n.d. & n.d. & n.d. & n.d. & n.d. & n.d. \\
\hline ZEN-d ${ }_{6}{ }^{\mathrm{a}}$ & 91 & 81 & 73 & 78 & 114 & 124 & 101 & 127 \\
\hline ZEN & n.d. & n.d. & n.d. & n.d. & 18.8 & n.d. & n.d. & n.d. \\
\hline \multirow{2}{*}{ Compounds } & \multicolumn{3}{|c|}{ June/2015 } & & \multicolumn{3}{|c|}{ July/2015 } & \\
\hline & P1 & P2 & P3 & P4 & P1 & P2 & P3 & P4 \\
\hline$\beta-Z A L$ & n.d. & n.d. & $<40^{\mathrm{b}}$ & n.d. & n.d. & n.d. & n.d. & n.d. \\
\hline$\beta-Z E L$ & n.d. & n.d. & n.d. & n.d. & n.d. & n.d. & n.d. & n.d. \\
\hline$\alpha-Z A L$ & n.d. & n.d. & n.d. & n.d. & n.d. & n.d. & n.d. & n.d. \\
\hline$\alpha-Z E L$ & n.d. & n.d. & n.d. & n.d. & n.d. & n.d. & n.d. & n.d. \\
\hline ZAN & n.d. & n.d. & 19 & n.d. & n.d. & n.d. & n.d. & n.d. \\
\hline ZEN- $\mathrm{d}_{6}{ }^{\mathrm{a}}$ & 117 & 119 & 119 & 88 & 102 & 103 & 98 & 88 \\
\hline ZEN & 14 & 12 & 11 & $<8^{\mathrm{b}}$ & n.d. & n.d. & n.d. & n.d. \\
\hline
\end{tabular}


All analytes were detected at least once at each point over the sampling period. ZEN compound had a higher frequency of detection $(52.5 \%)$, followed by $\alpha$-ZAL (12.5\%), $\beta$-ZAL (5.0\%), ZAN (5.0\%), $\alpha$-ZEL (5.0\%) and $\beta$-ZEL (2.5\%). A total of $47.5 \%$ of the samples had concentrations above the limit of quantification (LOQ), ranging from 11 to $59 \mathrm{ng} \mathrm{L}^{-1}$. Among the six analytes, ZEN was determined at all sampling points in five of the sampling campaigns performed. The highest levels were determined during the period of greatest rainfall. In addition, most ZEN metabolites were detected during the rainy season. The compounds $\beta$-ZAL, $\alpha$-ZAL and ZAN were quantified only once, whereas $\alpha$-ZEL and $\beta$-ZEL did not present in concentrations above the LOQ (Tab. 1). The limits of detection were for $\beta$-ZAL and $\beta$-ZEL of $20 \mathrm{ng} \mathrm{L^{-1 }}$, for $\alpha$-ZAL and $\alpha-Z E L$ of $8 \mathrm{ng} \mathrm{L}^{-1}$ and for ZAN and ZEN of $4 \mathrm{ng} \mathrm{L}^{-1}$.

The results obtained in this work are comparable to those obtained by other researchers. In previous studies, the detection frequencies for ZEN ranged from 0 to $30 \%$ and differed according to the seasons during sampling ${ }^{9,20-22}$. The highest concentrations of ZEN (up to $96 \mathrm{ng} \mathrm{L}^{-1}$ ) were detected in small streams or channels near agricultural fields with crops contaminated by Fusarium sp. ${ }^{9,20,23}$. Low levels (up to $35 \mathrm{ng} \mathrm{L}^{-1}$ ) were found in river and lake waters ${ }^{18,22-25}$. The metabolites $\beta$-ZAL and $\alpha$-ZAL were investigated in two rivers contaminated by wastewater effluents $^{24}$. The maximum concentration of both compounds was $3 \mathrm{ng} \mathrm{L}^{-1}$. The concentrations of $\beta$ ZEL and $\alpha$-ZEL metabolites were investigated in agricultural streams upstream and downstream of the WWTP in New York (USA). In agricultural fields, the concentrations of these compounds were generally below the limit of detection, but the highest detected concentrations reached tens or even hundreds of $n g \mathrm{~L}^{-1}$. In summary, the levels of estrogenic mycotoxins detected in rivers, streams and drainage channels occurred generally at levels of dozens of $\mathrm{ng} \mathrm{L}^{-1}$. However, much higher concentrations have occasionally been reported (single study), such as the detection of hundreds of ng $\mathrm{L}^{-1}$ for $\alpha$-ZEL and $\beta$-ZEL in streams near agricultural areas or wastewater effluents in New York, USA ${ }^{9}$.

The results obtained for physical, chemical and microbiological parameters at the sampling sites (Tab. 2) showed that variables such as fecal coliforms (December-July), BOD 5 (October and January), total phosphorus (October), nitrite concentration (December), and total ammoniacal nitrogen concentration (October) exceeded the values established by CONAMA for class 2 freshwater (Brazilian Environmental Council) ${ }^{26}$.

According to the results of these parameters (Tab. 2), there was increase in the total phosphorus, potassium concentration, total dissolved solids and turbidity during the rainy season (November to March), which was characteristic of rainfall events and the corresponding transport of fine soil particles into the body of water. There was an increase in the concentration total nitrogen during the extensive dry season in October 2014. It is assumed that the high concentration of ammoniacal nitrogen ( $42 \mathrm{mg} \mathrm{L}^{-1}$ for $\mathrm{P} 2$ site) probably originated from runoff waters that carried residues from livestock animals or by the drainage of agricultural soils where animal excrement was used as fertilizer.

The fecal contamination indicator (fecal coliforms) exceeded the maximum limit of $1000 \mathrm{CFU} 100 \mathrm{~mL}^{-124}$ in samples from all months, with the exception of October and November 2014. These results indicated that Rico Stream is subject to a great anthropogenic influence, probably related to the use and soil occupation of this microbasin. The Rico Stream microbasin presents serious problems of environmental degradation, characterized by residential and rural areas with large deforestation events and lack of adequate management of animal husbandry waste, resulting in contamination of the whole drainage network.

The P2 site had the highest concentrations of eight of the hydrological variables (fecal coliforms, BOD, total phosphorous, nitrate, nitrite, potassium, total dissolved solids, ammoniacal nitrogen concentrations), including 14 values above CONAMA legislation. This sampling site is characterized by tributaries that drain from the urban area of the Monte Alto municipality and is located downstream of the effluent discharge of the wastewater treatment plant (WWTP) (site that receives the highest contribution among others).

Soil occupation and land use in the area of the Rico Stream consists of small farms with diversified production. According to field observations during the sampling period, horticulture, swine and several agricultural crops (especially sugarcane and peanuts) were present in the area. The presence of mechanized irrigation of agricultural crops during both the dry and rainy periods was also observed during the sampling period. It may be inferred that the presence of 
estrogenic mycotoxins in the Rico Stream was probably due to effluent discharge from the WWTP of Monte Alto municipality (detection in downstream of the WWTP - P2 site), runoff from livestock facilities or fields receiving livestock manure applications (detection in upstream of the WWTP - P1 site). Rico Stream contamination from fungi in agricultural crops is unlikely since maize (temporary tillage) is insignificant in the region.

Table 2. Data on physicochemical and microbiological parameters determined in Rico Stream micro-basin over the period of sampling.

\begin{tabular}{|c|c|c|c|c|c|c|c|c|c|c|c|c|c|}
\hline Month & $\begin{array}{l}\text { Sampling } \\
\text { sites }\end{array}$ & $\begin{array}{c}\text { Fecal } \\
\text { coliforms } \\
(\mathrm{CFU} \\
\left.100 \mathrm{~mL}^{-1}\right)\end{array}$ & $\begin{array}{c}\text { Total } \\
\text { organic } \\
\text { carbon } \\
\left(\mathbf{m g ~ L}^{-1}\right)\end{array}$ & $\begin{array}{l}\text { Chemical } \\
\text { oxygen } \\
\text { demand } \\
\left(\mathrm{mg} \mathrm{L}^{-1}\right)\end{array}$ & $\begin{array}{c}\text { Biological } \\
\text { oxygen } \\
\text { demand } \\
\left(\mathrm{mg} \mathrm{L}^{-1}\right)\end{array}$ & $\begin{array}{c}\text { Total } \\
\text { phosphorus } \\
\left(\mathbf{m g ~ L} \mathbf{L}^{-1}\right)\end{array}$ & $\begin{array}{l}\text { Nitrate } \\
\left(\mathbf{m g ~ L}^{-1}\right)\end{array}$ & $\begin{array}{l}\text { Nitrite } \\
\left(\mathbf{m g ~ L ^ { - 1 }}\right)\end{array}$ & $\begin{array}{c}\text { Total } \\
\text { nitrogen } \\
\left(\mathbf{m g} \mathbf{L}^{-1}\right)\end{array}$ & $\begin{array}{c}\text { Total } \\
\text { ammoniacal } \\
\text { nitrogen } \\
\left(\mathbf{m g ~ L}^{-1}\right)\end{array}$ & $\begin{array}{c}\text { Total } \\
\text { dissolved } \\
\text { solids } \\
\left(\mathbf{m g ~ L}^{-1}\right)\end{array}$ & $\begin{array}{l}\text { Potassium } \\
\left(\mathbf{m g ~ L}^{-1}\right)\end{array}$ & $\begin{array}{c}\text { Turbidity } \\
\text { (NTU) }\end{array}$ \\
\hline \multirow{4}{*}{$\begin{array}{c}\text { October } \\
2014\end{array}$} & P1 & 850 & 10 & 24 & 5 & 0.098 & 1.0 & $<0.011$ & 46 & 0.30 & 112 & $<1.109$ & 11 \\
\hline & P2 & 65 & 72 & 180 & 81 & 1.820 & 3.4 & 0.621 & 46 & 42 & 343 & $<1.109$ & 16 \\
\hline & P3 & 22 & 16 & 40 & 15 & 0.230 & $<1.0$ & $<0.011$ & 0.5 & 0.51 & 132 & $<1.109$ & 7 \\
\hline & P4 & 40 & 21 & 52 & 30 & 0.176 & 5.5 & 0.040 & 6.0 & 0.50 & 159 & $<1.109$ & 10 \\
\hline \multirow{4}{*}{$\begin{array}{c}\text { November } \\
2014\end{array}$} & P1 & $<1.0$ & 9 & 23 & 5 & 0.123 & 6.3 & $<0.011$ & 6.5 & 0.21 & 210 & 6.162 & 13 \\
\hline & P2 & 500 & 16 & 40 & $<5.0$ & 0.420 & 7.2 & $<0.011$ & 10 & 2.90 & 184 & 5.217 & 12 \\
\hline & P3 & $<1.0$ & 22 & 55 & $<5.0$ & 0.120 & 5.7 & $<0.011$ & 5.9 & 0.20 & 168 & 6.801 & 12 \\
\hline & P4 & 70 & 8 & 20 & $<5.0$ & 0.181 & 6.2 & $<0.011$ & 6.4 & 0.25 & 198 & 5.209 & 13 \\
\hline \multirow{4}{*}{$\begin{array}{c}\text { December } \\
2014\end{array}$} & P1 & 2300 & 5 & 12 & $<5.0$ & 0.055 & 0.33 & 0.024 & 0.5 & 0.16 & 48 & 2.482 & 14 \\
\hline & P2 & 2200 & 5 & 12 & $<5.0$ & 0.707 & 0.78 & 1.301 & 2.4 & 0.26 & 83 & 4.091 & 16 \\
\hline & P3 & 3300 & 6 & 17 & $<5.0$ & 0.059 & 0.75 & 0.032 & 0.9 & 0.13 & 48 & 2.719 & 15 \\
\hline & P4 & 3900 & 2 & 4 & $<5.0$ & 0.072 & 2.6 & 0.026 & 2.7 & 0.11 & 47 & 3.073 & 15 \\
\hline \multirow{4}{*}{$\begin{array}{c}\text { January } \\
2015\end{array}$} & P1 & 600 & 14 & 37 & 15 & $<0.050$ & $<1.0$ & 0.020 & 0.4 & 0.12 & 94 & 1.593 & 4 \\
\hline & P2 & 20000 & 72 & 187 & 94 & 1.157 & 1.1 & 0.355 & 6.4 & $<0.05$ & 111 & 3.892 & 7 \\
\hline & P3 & 5000 & 16 & 41 & 21 & $<0.050$ & $<1.0$ & 0.036 & 0.3 & $<0.05$ & 138 & 1.946 & 46 \\
\hline & P4 & 6000 & 11 & 29 & 13 & $<0.050$ & 1.6 & 0.032 & 2.3 & 0.25 & 132 & 2.034 & 58 \\
\hline \multirow{4}{*}{$\begin{array}{l}\text { February } \\
2015\end{array}$} & P1 & 95 & $<0.04$ & 18 & $<5.0$ & $<0.050$ & $<1.0$ & 0.013 & 0.2 & $<0.05$ & 53 & 7.53 & 12 \\
\hline & P2 & 48 & $<0.04$ & 18 & $<5.0$ & $<0.050$ & $<1.0$ & 0.118 & 0.5 & 0.06 & 92 & 11.07 & 19 \\
\hline & P3 & 165 & $<0.04$ & 22 & $<5.0$ & $<0.050$ & $<1.0$ & 0.029 & 0.2 & $<0.05$ & 54 & 7.699 & 14 \\
\hline & $\mathrm{P} 4$ & 1100 & $<0.04$ & 11 & $<5.0$ & $<0.050$ & 3.8 & 0.071 & 4.0 & 0.14 & 54 & 9.994 & 15 \\
\hline \multirow{4}{*}{$\begin{array}{l}\text { March } \\
2015\end{array}$} & P1 & 61 & 8 & 19 & $<5.0$ & $<0.050$ & $<1.0$ & 0.068 & 0.4 & 0.15 & 44 & 3.237 & 10 \\
\hline & P2 & 620 & 22 & 54 & $<5.0$ & 0.196 & $<1.0$ & 0.143 & 0.6 & 0.24 & 62 & 4.396 & 11 \\
\hline & P3 & 380 & 5 & 12 & $<5.0$ & $<0.050$ & $<1.0$ & 0.069 & 0.6 & 0.36 & 40 & 3.886 & 56 \\
\hline & P4 & 3100 & 5 & 12 & $<5.0$ & 0.037 & 1.3 & 0.100 & 2.0 & 0.34 & 40 & 3.611 & 37 \\
\hline \multirow{4}{*}{$\begin{array}{l}\text { April } \\
2015\end{array}$} & P1 & 140 & $<0.04$ & $<4$ & $<5.0$ & $<0.050$ & 1.0 & $<0.011$ & 1.9 & 0.54 & 50 & 2.165 & 10 \\
\hline & P2 & 510 & 22 & 54 & $<5.0$ & 0.237 & 12 & 0.108 & 14 & 1.82 & 90 & 4.569 & 10 \\
\hline & P3 & 1100 & 19 & 46 & $<5.0$ & $<0.050$ & 2.3 & 0.036 & 2.8 & 0.29 & 50 & 2.286 & 92 \\
\hline & P4 & 900 & 35 & 84 & $<5.0$ & $<0.050$ & 4.0 & 0.016 & 4.5 & 0.15 & 46 & 2.796 & 74 \\
\hline \multirow{4}{*}{$\begin{array}{l}\text { May } \\
2015\end{array}$} & P1 & 410 & 69 & 186 & $<5.0$ & $<0.050$ & 0.31 & 0.015 & 0.7 & 0.33 & 90 & 2.420 & 9 \\
\hline & P2 & 2000 & 136 & 367 & $<5.0$ & $<0.050$ & 9.0 & 0.019 & 10 & 0.44 & 152 & 3.230 & 11 \\
\hline & P3 & 4300 & 2 & 4 & $<5.0$ & $<0.050$ & 0.70 & 0.014 & 1.3 & 0.40 & 84 & 2.119 & 21 \\
\hline & $\mathrm{P} 4$ & 1200 & 40 & 108 & $<5.0$ & $<0.050$ & 2.3 & 0.011 & 2.5 & 0.09 & 84 & 2.276 & 19 \\
\hline \multirow{4}{*}{$\begin{array}{l}\text { June } \\
2015\end{array}$} & P1 & 1600 & 16 & 40 & $<5.0$ & $<0.050$ & 1.0 & 0.015 & 1.2 & 0.16 & 47 & 1.79 & 8 \\
\hline & P2 & 420 & 35 & 88 & $<5.0$ & $<0.050$ & 1.5 & 0.232 & 2.4 & 0.64 & 96 & 3.991 & 14 \\
\hline & P3 & 5000 & 22 & 56 & $<5.0$ & $<0.050$ & 0.8 & 0.020 & 0.9 & 0.07 & 42 & 1.892 & 14 \\
\hline & P4 & 960 & 21 & 52 & $<5.0$ & $<0.050$ & 3.4 & 0.047 & 3.4 & $<0.05$ & 42 & 2.232 & 13 \\
\hline \multirow{4}{*}{$\begin{array}{l}\text { July } \\
2015\end{array}$} & P1 & 200 & 42 & 86 & $<5.0$ & $<\mathrm{LQ}$ & 0.74 & $<\mathrm{LQ}$ & 0.7 & $<\mathrm{LQ}$ & 65 & 2.196 & 5.3 \\
\hline & P2 & 3600 & 57 & 93 & $<5.0$ & 1.649 & 2.0 & 0.374 & 2.4 & $<\mathrm{LQ}$ & 106 & 3.671 & 9.7 \\
\hline & P3 & 2700 & 9 & 33 & $<5.0$ & $<\mathrm{LQ}$ & 0.87 & $<\mathrm{LQ}$ & 0.9 & $<L Q$ & 89 & 2.536 & 12.2 \\
\hline & P4 & 5200 & 12 & 29 & $<5.0$ & 0.033 & 4.6 & 0.044 & 4.6 & $<\mathrm{LQ}$ & 76 & 2.474 & 9.26 \\
\hline
\end{tabular}




\subsection{Estrogenicity}

The calculated cEEQ values ranged from $<0.03$ to $1.4 \mathrm{ng} \mathrm{L}^{-1}$ (mean value) (Tab. 3). The highest values of cEEQ were for $\alpha$-ZAL, even though the maximum concentration calculated in the samples was lower than those obtained for ZEN, as $\alpha$-ZAL showed the highest relative estrogenic potency among the quantified mycotoxins. The cEEQ values for the estrogenic mycotoxins in this study (Tab. 3) were higher than those reported in natural waters in Europe and USA $\left(<0.01 \text { to } 0.63 \mathrm{ng} \mathrm{L}^{-1}\right)^{27}$, except for the study performed by Kolpin et al. ${ }^{9}$, in which the highest value of cEEQ was calculated (New York, USA) for $\alpha$-ZEL ( $<8.8$ to $388 \mathrm{ng} \mathrm{L}^{-1}$ ).

In the specific case of ZEN, some adverse effects have been detected in vivo at concentrations comparable in this study. ZEN concentrations between 2 and $50 \mathrm{ng} \mathrm{L}^{-1}$ (lowest observed effect concentration - LOEC), activation of genes that regulate the growth and reproduction of fish (Pimephales promelas) has been reported ${ }^{28}$. The concentrations of ZEN reported in this work (Tab. 1) were higher or comparable to the LOEC from in vivo studies (fish) ${ }^{28}$.

Table 3. Concentration range, cEEQ and relative estrogenic potency of the analytes in the Rico Stream microbasin.

\begin{tabular}{|c|c|c|c|c|}
\hline Compounds & Concentration range $\left(\mathrm{ng} \mathrm{L}^{-1}\right)$ & cEEQ $^{a}$ (mean value) $\left(\right.$ ng L L $\left.^{-1}\right)$ & ${\text { cEEQ } \text { range }^{\mathrm{b}}\left(\mathrm{ng} \mathrm{L}^{-1}\right)}^{-1}$ & $\mathbf{R P}^{\mathbf{c}}$ \\
\hline ZEN & $<4.0^{\mathrm{d}}-59$ & $<0.03-0.47$ & $<0.01-5.0$ & $7.87 \times 10^{-3}$ \\
\hline ZAN & $<4.0^{\mathrm{d}}-19$ & $<0.07-0.33$ & $<0.02-3.1$ & $1.76 \times 10^{-2}$ \\
\hline$\alpha-Z A L$ & $<8.0^{\mathrm{d}}-27$ & $<0.42-1.4$ & $<0.15-4.7$ & $5.20 \times 10^{-2}$ \\
\hline$\beta-\mathrm{ZAL}$ & $<20^{\mathrm{d}}-48$ & $<0.43-1.0$ & $<0.09-2.3$ & $2.14 \times 10^{-2}$ \\
\hline
\end{tabular}

${ }^{a}$ Mean cEEQs were calculated from individual mycotoxin concentrations multiplied by the geometric mean of relative estrogenic potencies (RPs) of analytes from different in vitro systems

${ }^{b}$ cEEQs ranges were calculated as the concentrations of mycotoxins multiplied by the minimum and maximum RPs of the analytes from different in vitro systems

${ }^{\mathrm{c}}$ Geometric mean of the relative estrogenic potencies ${ }^{27}$

${ }^{\mathrm{d}} \mathrm{LOD}$ value

\section{Conclusions}

In this study, it was concluded that estrogenic mycotoxins are present along the Rico Stream microbasin and that the contribution routes of these compounds are the run-off from livestock farming practices, drainage of agricultural soils from animal manure or wastewater treatment plant effluent from Monte Alto city. Additionally, this is the first report of estrogenic mycotoxins in environmental waters in Brazil. All estrogenic mycotoxins were detected at some point during the study, and quantifiable concentrations (11 to $59 \mathrm{ng} \mathrm{L}^{-1}$ ) were similar to those found in studies conducted in other countries that are influenced by agricultural areas, livestock around river waters, as well as waterbodies that receive WWTP effluents. Thus, our results can contribute to discussion of the improvement of the water and sewage treatment in Brazil, as well as to the development of global environmental legislation.

\section{Acknowledgments}

E. S. Emídio is grateful for the doctoral student fellowship from $\mathrm{CNPq}$ (Brazilian National Counsel of Technological and Scientific Development). Research support was provided by the FACTE Foundation for Science, Technology and Education Support. The authors are grateful to Dr. Laudicéia Giacometti Lopes and SAAJ for providing the sampling logistics.

\section{References}

[1] Escrivá, L., Font, G., Manyes, L., In vivo toxicity studies of Fusarium mycotoxins in the last decade: a review, Food and Chemical Toxicology 78 (2015) 85206. https://doi.org/10.1016/j.fct.2015.02.005.

[2] Pamplona-Silva, M. T., Mazzeo, D. E. C., Bianchi, J., Marin-Morales, M. A., Estrogenic compounds: chemical characteristics, detection methods, biological and environmental effects, Water, Air, \& Soil Pollution 229 (144) (2018) 1-27. https://doi.org/10.1007/s11270018-3796-z. 
[3] Schwartz, P., Thorpe, K. L., Bucheli, T. D., Wettstein, F. E., Burkhardt-Holm, P., Short-term exposure to the environmentally relevant estrogenic mycotoxin zearalenone impairs reproduction in fish, Science of The Total Environment 409 (2) (2010) 326333. https://doi.org/10.1016/j.scitotenv.2010.10.017.

[4] Oliveira, M. S., Rocha, A., Sulyok, M., Krska, R., Mallmann, C. A., Natural mycotoxin contamination of maize (Zea mays L.) in the South region of Brazil, Food Control $73 \quad$ (Part B) (2017) 127-132. https://doi.org/10.1016/j.foodcont.2016.07.033.

[5] Dors, G. C., Bierhals, V. da S., Badiale-Furlong, E., Parboiled rice: chemical composition and the occurrence of mycotoxins, Food Science and

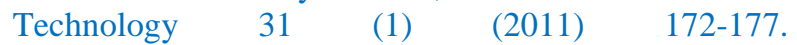
https://doi.org/10.1590/S0101-20612011000100025.

[6] Tibola, C. S., Fernandes, J. M. C., Guarienti, E. M., Effect of cleaning, sorting and milling processes in wheat mycotoxin content, Food Control 60 (2016) 174179. https://doi.org/10.1016/j.foodcont.2015.07.031.

[7] Santin, E., Maiorka, A., Zanella, I., Magon, L., Micotoxinas do Fusarium spp na avicultura comercial, Ciência Rural $31 \quad$ (1) (2001) 185-190. https://doi.org/10.1590/S0103-84782001000100030.

[8] Shore, L. S., Shemesh, M., Estrogen as an environmental pollutant, Bulletin of Environmental Contamination and Toxicology 97 (2006) 447-448. https://doi.org/10.1007/s00128-016-1873-9.

[9] Kolpin, D. W., Schenzel, J., Meyer, M. T., Phillips, P. J, Hubbard, L. E., Scott, T.-M., Bucheli, T. D., Mycotoxins: diffuse and point source contributions of natural contaminants of emerging concern to streams, Science of The Total Environment 470-471 (2014) 669676. https://doi.org/10.1016/j.scitotenv.2013.09.062.

[10] Lundgren, M. S., Novak, P. J., Quantification of phytoestrogens in industrial waste streams, Environmental Toxicology and Chemistry 28 (11) (2009) 2318-2323. https://doi.org/10.1897/09-029.1.

[11] Pessoa, G. P., Santos, A. B. dos, Souza, N. C. de, Alves, J. A. C., Nascimento, R. F. do, Development of methodology to determine estrogens in wastewater treatment plants, Química Nova 35 (5) (2012) 968-973. https://doi.org/10.1590/S0100-40422012000500019.

[12] Schenzel, J., Hungerbühler, K., Bucheli, T. D., Mycotoxins in the environment: II. Occurrence and origin in Swiss river waters, Environmental Science \& Technology $46 \quad$ (24) (2012) 13076-13084. https://doi.org/10.1021/es301558v.
[13] Zanini, H. L. H. T., Amaral, L. A. do, Zanini, J. R., Tavares, L. H. S., Caracterização da água da microbacia do córrego rico avaliada pelo índice de qualidade de água e de estado trófico, Engenharia Agrícola 30 (4) (2010) 732-741. https://doi.org/10.1590/S010069162010000400017 .

[14] Centro de Pesquisas Meteorológicas e Climáticas Aplicadas à Agricultura (CEPAGRI), Clima dos Municípios Paulistas. 2018.

[15] Pissarra, T. C. T., Rodrigues, F. M., Politano, W., Galbiatti, J. A., Morfometria de microbacias hidrográficas do córrego Rico, afluente do Rio MogiGuaçú, Estado de São Paulo, Brasil, Revista Árvore 34 (4) (2010) 669-676. https://doi.org/10.1590/S010067622010000400011 .

[16] Takahashi, E. L. H., Rosa, F. R. T., Langeani, F., Nakaghi, L. S. O., Spatial and seasonal patterns in fish assemblage in Córrego Rico, upper Paraná River basin, Neotropical Ichthyology 11 (1) (2013) 143-152. https://doi.org/10.1590/S1679-62252013000100017.

[17] Emídio, E. S., Silva, C. P. da, Marchi, M. R. R. de, Determination of estrogenic mycotoxins in environmental water samples by low-toxicity dispersive liquid-liquid microextraction and liquid chromatography-tandem mass spectrometry, Journal of $\begin{array}{lllll}\text { Chromatography } & \text { A. } & 1391 & \text { (2015) } & \text { 1-8. }\end{array}$ https://doi.org/10.1016/j.chroma.2015.02.067.

[18] American Public Health Association (APHA), American Water Works Association (AWWA), Water Environment Federation (WEF), Standard Methods for the Examination of Water and Wastewater, American Public Health Association, Washington, 21th ed., 2005.

[19] Jarošová, B., Bláha, L., Giesy, J. P., Hilscherová, $\mathrm{K}$., What level of estrogenic activity determined by in vitro assays in municipal waste waters can be considered as safe?, Environment International 64 (2014) 98-109. https://doi.org/10.1016/j.envint.2013.12.009.

[20] Gromadzka, K., Waśkiewicz, A., Goliński, P., Świetlik, J., Occurrence of estrogenic mycotoxin zearalenone in aqueous environmental samples with various NOM content, Water Research 43 (4) (2009) 1051-1059.

https://doi.org/10.1016/j.watres.2008.11.042.

[21] Hartmann, N., Erbs, M., Forrer, H.-R., Vogelgsang, S., Wettstein, F. E., Schwarzenbach, R. P., Bucheli, T. D., Occurrence of zearalenone on Fusarium graminearum infected wheat and maize fields in crop organs, soil, and drainage water, Environmental Science \& Technology 42 (15) (2008) 5455-5460. https://doi.org/10.1021/es8007326. 
[22] Maragos, C. M., Zearalenone occurrence in surface waters in central Illinois, USA, Journal Food Additives \& Contaminants: Part B Surveillance 5 (1) (2012) 5564. https://doi.org/10.1080/19393210.2012.659764.

[23] Bucheli, T. D., Wettstein, F. E., Hartmann, N., Erbs, M., Vogelgsang, S., Forrer, H.-R., Schwarzenbach, R. P., Fusarium mycotoxins: overlooked aquatic micropollutants?, Journal of Agricultural and Food Chemistry 56 (3) (2008) 10291034. https://doi.org/10.1021/jf073082k.

[24] Laganà, A., Bacaloni, A., De Leva, I., Faberi, A., Fago, G., Marino, A., Analytical methodologies for determining the occurrence of endocrine disrupting chemicals in sewage treatment plants and natural waters, Analytica Chimica Acta 501 (1) (2004) 79-88. https://doi.org/10.1016/j.aca.2003.09.020.

[25] Kolpin, D. W., Hoerger, C. C., Meyer, M. T., Wettstein, F. E., Hubbard, L. E., Bucheli, T. D., Phytoestrogens and mycotoxins in Iowa Streams: an examination of under investigated compounds in agricultural basins, Journal of Environmental Quality 39 (6) 2089-2099. https://doi.org/10.2134/jeq2010.0121.

[26] Conselho Nacional do Meio Ambiente (CONAMA), Resolução n 357 de 17 de março de 2005, Ministério do Meio Ambiente (2005) 1-27. http://www.mma.gov.br/port/conama/res/res05/res3570 5.pdf.

[27] Jarošová, B., Javůrek, J., Adamovský, O., Hilscherová, K., Phytoestrogens and mycoestrogens in surface waters-their sources, occurrence, and potential contribution to estrogenic activity, Environment International $\quad 81 \quad$ (2015) 26-44. https://doi.org/10.1016/j.envint.2015.03.019.

[28] Johns, S. M., Denslow, N. D., Kane, M. D., Watanabe, K. H., Orlando, E. F., Sepúlveda, M. S., Effects of estrogens and antiestrogens on gene expression of fathead minnow (Pimephales promelas) early life stages, Environmental Toxicology 26 (2) (2011) 195-206. https://doi.org/10.1002/tox.20545. 